\title{
Sytuacja językowa w Unii Europejskiej
}

\author{
JANUSZ B AŃCZEROWSKI \\ Univerza Loránda Eötvösa, Filozofska fakulteta, ELTE BTK Szláv Tánszék, \\ Múzeum krt.4/D, HU-1088Budapest, bjanusz@ludens.elte.hu
}

SCN II/1 [2009], 12-19

Vprašanje jezika in kulture v EZ je zelo zapleteno in si ga ni mogoče predstavljati brez upoštevanja rezultatov medjezikovnih in medkulturnih raziskav. Državljane EZ je potrebno soočiti s kulturno in civilizacijsko raznolikostjo, ki jo je potrebno razumeti pravilno in ne kot grožnjo svoji narodni identiteti. Je izobražen prebivalec EZ pripravljen na soočenje z jezikovno, kulturno in civilizacijsko raznolikostjo? Jo znajo državljani EZ ustrezno obravnavati in sprejeti? Kaj so pripravljeni storiti, da bi ohranili in kultivirali svoj lastni jezik, kulturo in identiteto ter jih posredovali naslednji generaciji? To so izzivi, s katerimi se morajo soočiti narodi in suverene države. Nove članice EZ so po dolgi izolaciji bile nenadoma izpostavljene integraciji in globalizaciji.

Issues of language and culture in the EU exhibit a complex pattern, and their proper management cannot be conceived of without taking into consideration the results of interlinguistic and intercultural research. EU citizens must be prepared to confront cultural and civilizational diversity and also to understand that diversity rather than receiving it as a threat to their national identity. Are educated EU citizens, for example, ready to come to grips with linguistic, cultural and civilizational diversity? Are they able to adequately treat and accept such diversity? What are they prepared to do in order to maintain and cultivate their own language, culture, and identity, as well as to hand them down to the next generation? These are the challenges that a nation and a sovereign state necessarily have to face. New EU member states, torn out of its former isolation, has suddenly found itself exposed to globalization processes.

Ključne besede: medjezikovni in medkulturni globalizacijski procesi, jezikovna politika, medkulturni dialog, večjezičnost EZ, mali in veliki jeziki EU

Key words: interlinguistic and intercultural globalization processes, language policy, intercultural dialogue, linguistic pluralism in the EU, little and big languages and cultures 
Zachodzące w obecnym świecie procesy integracyjne i globalizacyjne przenikają nieomal wszystkie sfery życia społeczeństw, państw i narodów. W gruncie rzeczy są to procesy unifikacyjne prowadzące do zatarcia specyfiki narodowej, a co za tym idzie i tożsamości językowo-kulturowej. Zjawisko to nie jest zresztą czymś zupełnie nowym w historii ludzkości. Integracja i następująca po niej dezintegracja zawsze wyznaczały porządek tego świata, pozostawiając po sobie określone skutki. Aby się o tym przekonać wystarczy spojrzeć na wiek XX, w którym rozpadło się aż sześć imperiów (cesarstw) (Brytyjskie, Rosyjskie, Niemiecko-Pruskie, Austriacko-Węgierskie, Osmańskie, Japońskie i ZSRR), powodując ogromne zmiany nie tylko na językowej i kulturowej mapie świata.

Obecnie jesteśmy świadkami integrującej się Europy, dalece zróżnicowanej pod względem językowym i kulturowym. Różnorodność językowych i kulturowych obrazów świata jednoczących się wspólnot narodowych zakłada konieczność współżycia różnych języków i kultur w ramach jednego organizmu unijnego. Trzeba sobie jednak wyraźnie zdawać sprawę z tego, że w językowych i kulturowych obrazach świata poszczególnych wspólnot komunikacyjnych utrwalone zostały specyficzne dla nich sposoby widzenia świata, jego kategoryzacji i konceptualizacji. Ścisły związek języka z różnymi sferami życia danej wspólnoty kulturowej nadaje mu specyficzny koloryt narodowy, co w literaturze fachowej zwykło się nazywać lingworealiami. Na sferę znaczenia leksykalnego nakładają się, jak wiadomo, różnego rodzaju metainformacje w postaci znaczeń ekspresywnych, estetycznych, moralnych, ideologicznych, pragmatycznych, historycznokulturowych i in., innymi słowy tzw. komponent narodowokulturowy. Chodzi tu o zjawiska właściwe kulturze danej wspólnoty językowej związane z wzorcami kulturowymi, obyczajami, zwyczajami, przekonaniami, mentalnością, tradycją, folklorem, systemem aksjologicznym, specyfiką struktury życia społeczno-politycznego itp. Będzie to tzw. idiomatyka socjokulturowa (frazeologizmy obrazowe, utarte powiedzenia, przysłowia, sentencje, maksymy, wyrażenia antroponimiczne, wyrażenia toponimiczne, syntagmy konwencjonalne, lotne słówka, aforyzmy, hasła i dewizy).

Globalizacyjne procesy interlingwalne i interkulturowe mogą zmienić w sposób zasadniczy dotychczasowy model życia poszczególnych narodów i grup etnicznych. W tym kontekście warto przytoczyć słowa byłego przewodniczącego Wspólnoty Europejskiej Jacques Delors'a: „Problem językowy dotyka korzeni Wspólnoty Europejskiej. Język jest częścią narodowej i osobowej tożsamości, także języki europejskie są częścią wielkiego dziedzictwa kulturowego tego kontynentu. Jeżeli wspólnota będzie nadal rozrastała się, na pewno zwiększą się jej praktyczne trudności oddania należnego szacunku językom swoich państw-członków. Jednak każde rozwiązanie, które to ignorowałoby, zachwiałoby podstawami koncepcji naszej wspólnoty“ (Cyt. za D. Blanke 2004: 52).

W związku z nasilającymi się aktualnie na całym świecie, a tym samym i w Europie procesami integracyjnymi i globalizacyjnymi powstaje pytanie, jaka bliższa i dalsza perspektywa zarysowuje się przed małymi językami i kulturami? Czy będą one w stanie zachować swoją tożsamość w obliczu ogromnej 
i wielostronnej konkurencji, której warunki dyktują języki światowe, czy też zostaną zepchnięte na peryferie, ulegną degradacji i utracą swoją pierwotną funkcję. Pojęcie konkurencji zakłada istnienie zwycięzcy i zwyciężonego. Istnieje przekonanie, że już w najbliższej przyszłości w wielu krajach wśród mniejszości narodowych i emigrantów całkowicie upowszechni się nauczanie multilingwalne. W sytuacji wynikającego z pluralizmu kulturowego, migracji, powstania wspólnot ponadnarodowych, „europeizacji“, globalizacji i coraz bardziej nasilającego się „umiędzynarodowienia“ mediów publicznych należałoby ponownie określić pozycję języka narodowego, ponieważ obecny stan rzeczy sprzyja kształtowaniu się świadomości polikulturalnej.

Zachodzące w Europie i świecie procesy integracyjne i globalizacyjne spowodowały niezwykły wzrost zainteresowania problematyką komunikacji interkulturowej, co daje się zaobserwować m.in. w stale rosnącej liczbie publikacji naukowych na ten temat. Dialog kultur stał się przedmiotem badań wielu nauk humanistycznych (np. językoznawstwa, historii, psychologii, lingwodydaktyki, kulturologii, etnografii itd.). Wyniki tego typu badań naukowych mają ogromne znaczenie dla rozwoju stosunków międzyludzkich i międzynarodowych, komunikacji językowej, translatoryki, optymalizacji nauczania języków obcych itp. Warto zauważyć, że już sam rozwój językoznawstwa historyczno-porównawczego spowodował jednocześnie wśród językoznawców wzrost zainteresowania problematyką interkulturową. Procesy interlingwalne i interkulturowe były również przedmiotem badań językoznawstwa arealnego. W ten sposób w językoznawstwie powstał cały system terminów, pojęć i kategorii związany z kontaktami językowymi.

Dialog interkulturowy i intensywny, trwający przez dłuższy czas kontakt interlingwalny pozostają nie bez wpływu na leksykę i strukturę języków. W wyniku tego procesu dochodzi do zapożyczeń leksykalnych, przejmowania wzorców słowotwórczych i struktur syntaktycznych. Na przykład, włoska terminologia muzyczna, podobnie do grecko-łacińskich terminów języka medycyny, trafiła do wielu języków świata itp. Niektóre języki pełniły (pełnią) funkcję języków-pośredników. Język grecki i łaciński, jak wiadomo, pełniły w przeszłości funkcję języków międzynarodowych, sprzyjając tym samym wytworzeniu się ponadnarodowego poczucia tożsamości kulturowej. Podobnie dzieje się to i dzisiaj w przypadku ekspansji języka angielskiego.

Przyszła wspólna Europa kształtuje się jako organizm wielonarodowy i w związku z tym może nasunąć się m.in. pytanie, jak będzie przebiegało w nim współżycie różnych języków i kultur, i jak będzie wyglądała w praktyce polityka językowa? Powszechnie wiadomo, że problem językowy w Unii Europejskiej dyskutowano już wielokrotnie i opracowano nawet różne popozycje i zalecenia. Jednak w kręgach politycznych, z uwagi na dużą wrażliwość tego zagadnienia, problem ten zawsze próbowano omijać, chociaż w literaturze poświęconej polityce językowej udzielono mu sporo miejsca. Ogólnie odnosi się wrażenie, że w UE nie istnieje żaden problem językowy, niezależnie od tego, że status prawny języków państwowych i ich faktyczna pozycja w praktyce unijnej jest dalece zróżnicowana. Język angielski, francuski i ostatnio niemiecki pełnią funkcję 
tzW. głównych języków roboczych, tzn., że za ich pośrednictwem realizuje się codzienna praktyka komunikacyjna w instytucjach unijnych, natomiast pozostałe języki są jednocześnie i tzw. językami oficjalnymi (official language) i roboczymi (working language), przynajmniej według ich statusu prawnego, tzn. są identyczne z językami państwowymi. Niezależnie od pozornego spokoju w kwestii językowej za kulisami jednak sytuacja wygląda nieco inaczej. Rząd niemiecki np. czyni intensywne starania, aby umocnić pozycję języka niemieckiego jako głównego języka roboczego i nie wiadomo jeszcze, jaką postawę zajmą nowi członkowie wobec pozycji swoich języków w UE. Obecnie językami oficjalnymi UE są: język angielski, duński, fiński, francuski, grecki, holenderski, irlandzki, niemiecki, włoski, portugalski, hiszpański, szwedzki, bułgarski, czeski, estoński, litewski, łotewski, polski, rumuński, słowacki, słoweński, węgierski.

W dyskusjach i odnośnych publikacjach ciągle podkreśla się konieczność zachowania i umocnienia wielojęzyczności w UE, która niewątpliwie jest jednocześnie i zaletą i przeszkodą. Przyjęcie zasady równouprawnienia byłoby podejściem demokratycznym, ale nieekonomicznym i nieefektywnym. Z drugiej strony, postulowanie jednego czy kilku języków roboczych byłoby ekonomiczne, ale niedemokratyczne, ponieważ dawałby przywileje tym, którzy się tymi językami posługują. Podejście niedemokratyczne może utrudnić wewnętrzną integrację UE i być przyczyną konfliktów.

UE ma problemy nie tylko z konstytucją, budżetem, ostatnio także z kryzysem finansowym, ale również z tożsamością i wielojęzycznością. Już od dawna mówi się w Brukseli o potrzebie zmniejszenia liczby języków oficjalnych. Jedni chcieliby status ten zachować tylko w przypadku języka angielskiego, francuskiego i niemieckiego z uwagi na to, że eurokraci w codziennych kontaktach roboczych posługują się tylko tymi językami. Inni natomiast są zdania, że każdą rodzinę językową powinien reprezentować jeden język w funkcji oficjalnego. Przyjęcie takiej propozycji jest mało prawdopodobne, ponieważ przynajmniej na razie ani jeden kraj członkowski nie zamierza pozbawić swych obywateli możliwości komunikowania się z instytucjami UE w swoim własnym języku. Warto nadmienić, że przed ostatnim rozszerzeniem język irlandzki nie był językiem oficjalnym UE, niezależnie od tego, że jest on językiem oficjalnym w Irlandii. Dublin zrezygnował z niego twierdząc, że większość Irlandczyków posługuje się swobodnie językiem angielskim. Gdy natomiast na scenie UE pojawiły się małe języki, takie jak np. język estoński, łotewski, litewski, słowacki czy słoweński od razu rozgorzała dyskusja na temat statusu języka irlandzkiego, w wyniku której język irlandzki uznano za 21-szy język oficjalny UE. Pojawienie się w UE małych języków stał się argumentem dla tych, którzy chcieliby, aby odpowiedni status otrzymały również i takie języki, które wprawdzie istnieją na obszarze UE, ale nigdzie nie są językami państwowymi, np. język walijski czy kataloński (Obecnie w Europie istnieje ok. 200 języków). Katalończycy już od dawna domagają się oficjalnego statusu dla swojego języka, argumentując to tym, że językiem katalońskim posługuje się 13 milionów ludzi i dla 5 milionów jest on językiem ojczystym, a taki język jak np. słoweński, chociaż 
posługuje się nim tylko $2 \mathrm{mln}$. mieszkańców Słowenii jest językiem oficjalnym UE. Głównego argumentu dostarczyła jednak Malta, która domagała się statusu języka oficjalnego dla języka maltańskiego. Spowodowało to jednak poważny problem, ponieważ okazało się, że języka maltańskiego używa się jedynie w komunikacji prywatnej, natomiast cała prasa i dokumenty urzędowe ukazują się w języku angielskim. W międzyczasie okazało się, że oficjalnych tłumaczy z języka maltańskiego jest na świecie zaledwie 5 i rzekomo żaden z nich wcale nie kwapi się do pracy w Brukseli czy Strasburgu. Trudności tego typu wcale nie zniechęciły innych. Aspiracje językowe mniejszości narodowych w UE znacznie się nasiliły, gdy 397 tys. Maltańczyków uzyskało pełnoprawny status dla swego języka. Status języka półoficjalnego otrzymał również język kataloński, baskijski i galisyjski. Oznacza to, że na języki te będą tłumaczone wszystkie unijne akty prawne, ale nie w wersji oficjalnej. Koszty tłumaczeń będzie ponosił rząd hiszpański. Podobny status może otrzymać również język luksemburski, jeśli sami Luksemburczycy wyrażą takie życzenie. W świetle powyższych uwag warto przytoczyć tu również dane procentowe świadczące o znajomości języków obcych w poszczególnych państwach UE. W 1999 roku sytuacja ta wyglądała następująco: w Austrii - $57 \%$, w Belgii - $64 \%$, Danii $-84 \%$, w Wielkiej Brytanii - $19 \%$, w Finlandii - $59 \%$, we Francji - $41 \%$, w Grecji - $42 \%$, w Holandii - $91 \%$, w Irlandii - $28 \%$, w Luksemburgu $97 \%$, w Niemczech - $49 \%$, we Włoszech - $40 \%$, w Portugalii - $36 \%$, w Hiszpanii - $37 \%$, w Szwecji - $82 \%$. Oznacza to, że 56 \% ludności nie zna ani jednego języka obcego. Po rozszerzeniu UE w 2004-ym roku sytuacja ta znacznie się pogorszyła.

Według Forresta (1998: 107, cytuję za Blanke: 2004: 56) na pośrednictwo językowe Parlament UE przeznacza jedną trzecią swego budżetu. Johnston (2000: 39, cytuję za Blanke: 2004: 56) natomiast twierdzi, że koszty pośrednictwa językowego w UE wynoszą $40 \%$ wszystkich kosztów administracyjnych, co równa się $5 \%$ całego budżetu. Inni jednak podważają prawdziwość tych danych, motywując to tym, że nie uwzględniają one kosztów przeznaczonych na kształcenie tłumaczy, zaopatrzenie w niezbędne środki techniczne (np. wyposażenie kabin dla tłumaczy, materiały biurowe, kserowanie itp.). Oprócz tego, finansuje się również związane z tym różne projekty, dokształcanie tłumaczy, wymianę nauczycieli języków obcych itd. Obecnie brak jest dokładnych danych odnośnie kosztów, jakie ponoszą obywatele UE w związku z wielojęzycznością. Jedno jest pewne, że suma ta jest bardzo wysoka i w przyszłości będzie tylko rosnąć. Na przykład, według danych z 1999-ego roku koszty pośrednictwa językowego w UE wynosiły 685900000 euro, a w już w 2004-ym roku osiągnęły sumę ponad 800 milionów euro. Według brytyjskiego dziennika „The Independent“, biorąc pod uwagę tylko samo przyznanie irlandzkiemu oficjalnego statusu urzędowego języka obciążyło dodatkowo budżet unijny w wysokości ponad 677 tys. euro w 2007-ym roku. Nie trudno przewidzieć, że problem językowy już w najbliższej przyszłości może sprawić wiele poważnych kłopotów decydentom UE. UE ma obecnie 21 uznanych języków, co przy 25 członkach daje 380 możliwych kombinacji tłumaczeniowych i kosztuje 1 mld 
euro rocznie. Dla zapewnienia tłumaczeń na nowy uznany unijny język potrzeba utworzenia 9 nowych stanowisk tłumaczy.

Język, jak wiadomo, w naszej cywilizacji jest najwyższą wartością człowieka, który pełni nie tylko funkcję przekazu informacji, ale jest również podstawowym filarem kultury symbolicznej danego narodu, utrwalając tym samym jego specyfikę, a tym samym jego suwerenny byt. Nie trudno przewidzieć do czego doprowadziłaby utrata własnego języka, własnej kultury, własnej tożsamości narodowej. Jak pisze były prezes Węgierskiej Akdemii Nauk Ferenc Glatz: „Jest rzeczą oczywistą, że nowoczesną technikę, konflikty społeczne i światopoglądowe obecnego świata człowiek może zrozumieć właściwie tylko w języku ojczystym. Swój świat emocjonalny będzie on również i w przyszłości tworzył i rozwijał we własnym języku. Dlatego też należy modernizować małe języki. Jeśli nie będzie nauczania fizyki, chemii, biologii czy też literatury pięknej, poezji w języku węgierskim, słowackim, rumuńskim czy innym, wtedy dzieci z prowincji węgierskich, Podkarpacia itd. już w wieku sześciu lat znajdą się w o wiele gorszej sytuacji w stosunku do tych, które pochodzą z midwest lub wielkich kultur, mając na uwadze konkurencję światową, która na nich czeka" (Glatz 2001/7).

Jeżeli w danym języku zostanie przerwany przekaz międzypokoleniowy to oznacza to koniec istnienia tego języka. W chwili obecnej w Europie dotyczy to przede wszystkim takich języków jak: wepski (czudzki), wotski, ingryjski (iżorski) czy liwski z grupy bałtofińskiej używanych na obszarze między Petersburgiem a jeziorem Ładoga. (Język liwski używany jest na Łotwie, nad Zatoką Ryską.) Jak zauważa Bogdan Walczak „Wycofanie języka ojczystego z nauki, wyższych szczebli systemu oświatowego, środków masowego przekazu informacji itd. i ograniczenie go do sfery życia rodzinnego i prywatnego oznacza - w warunkach dwujęzyczności - początek końca. Dlatego faktycznie zagrożone są na przykład wszystkie języki celtyckie: irlandzki ... (mimo statusu języka państwowego - obok angielskiego - w Republice Irlandii), szkocki ..., walijski ... (tak czy owak najżywotniejszy dziś język celtycki) i bretoński (używany we francuskiej Bretanii) ... Wśród języków słowiańskich do zagrożonych należą języki łużyckie, w szczególności dolnołużycki ... Warto w tym miejscu przypomnieć, że nie znamy wypadku wskrzeszenia języka, który w ścisłym tego słowa znaczeniu wymarł" (Walczak 2007: 93-94). W kontekście powyższych uwag warto byłoby spojrzeć na dzisiejszą sytuację małych języków oficjalnych na obszarze UE, ponieważ, jak się wydaje, ich pozycja u progu trzeciego tysiąclecia zarówno wewnątrz danego kraju, jak i poza nim zauważalnie słabnie. Warto może przy okazji postawić pytanie, czy wykształcony obywatel UE jest przygotowany do konfrontacji z wielojęzycznością i wielokulturowością? I czy potrafi ją akceptować? 


\section{LITERATURA}

Géza BALÁZS, 1998: Magyar nyelvkultúra az ezredfordulón. A-Z. Budapest. - -, 2001: Magyar nyelvstratégia. Budapest: Magyar Tudományos Akadémia. Janusz BAŃCZEROWSKI, 1998: Kötelességünk-e gondoskodni anyanyelvünkről. Magyar Nyelv 1, 16-31.

- -, 2000: Nyelvközösségi és nyelvpolitikai kérdések - kihívások és lehetőségek. Magyar Nyelv 4, 391-402.

Detlev BLANKE, 2004: Języki w Unii Europejskiej i Niemcy o równouprawnieniu ... własnego języka. The Other (?) Europe. Poznań. 51-73.

Csaba FÖLDES, 2003: Interkulturelle Linguistik. Vorüberlegungen zu Konzepten, Problemen und Desiderata. Universitätsverlag Veszprém: Edition Praesens. 7-61.

Alan FORREST, 1998: The Challenge of Languages in Europe. „Terminologie et Traduction, la revue des services linguistiaues des institutions européenes (Luxemburg)“3. 113.

Károly GADÁNYI, János PUSZTAY (ur.), 2002: Közép-Európa: Egység és sokszinüség. Szombathely.

Ferenc GLATZ, 2001: Hét tézis az Európai Unióról és a nyelvekről. Lingua Frankák, regionális lingua frankák, anyanyelvek és a német nyelv. Magyar Tudomány 7, 853-861. http://www.matud.iif.hu/01jul/glatz.html.

László GRÉTSY, 1998: Nyelvhasználat és nemzeti tudat. Magyar Nyelv 1, 31-37.

Jenő KISS, 1997: A magyar nyelvröl - nyelvpolitikai megközelítésben. Magyar Tudomány 8, 957-969.

- -, 2001: Hagyomány, nyelv és nyelvközösség. MTA. Közgyülési előadások I. Budapest: Magyar Tudományos Akadémia. 63-69.

- -, 2006: Tünődések az Európai Unió nyelvi jövőjéröl. Interkulturális kommunikáció: nyelvi és kulturális sokszinüség Európában. Budapest: Eötvös Loránd Tudományegyetem, Bölcsészettudományi Kar, Magyar Tudományos Akadémia, Modern Filológiai Társaság. 84-87.

Ilona KOUTNY, 2004: Komunikacja międzykulturowa w Europie: angielski i esperanto jako alternatywne środki komunikacji. Inna(?) Europa. Poznań: Wydawnictwo-Drukarnia „Prodruk“. 73-96.

István NYOMÁRKAY, 2000: Kis nyelvek az európai csatlakozás küszöbén. Hungarológia 2, 53-62.

- -, 2004: Nyelveink múltja és jelene. Budapest: Opera Slavica Budapestinensia. Linguae Slavicae. Cathedra Philologiae Slavicae.

Bogdan WALCZAK, 2007: Język polski wśród języków świata u progu trzeciego tysiąclecia. Literatura, kultura i język polski w kontekstach i kontaktach światowych. Poznań: Wydawnictwo Naukowe UAM. 89-103. 


\section{JEZIKOVNI POLOŽAJ V EVROPSKI ZVEZI}

Integracijski in globalizacijski procesi sodobnega sveta določajo skoraj vsa področja življenja družb, držav in narodov. Gre za neke vrste poenotenje, ki lahko zabriše narodne značilnosti, posledično pa tudi jezikovno-kulturne identitete. Medjezikovni in medkulturni globalizacijski procesi lahko spremenijo dosedanji model življenja posameznih narodov in etničnih skupin. Pojavlja se vprašanje o perspektivah malih jezikov in kultur. V položaju, ki izvira iz kulturnega pluralizma migracij, nastajanja nadnarodnih skupnosti, »evropeizacije«, globalizacije in stopnjevane »internacionalizacije« javnih medijev, je potrebno na novo opredeliti položaj narodnega jezika. Medkulturni dialog in intenzivni, dolgotrajni medjezikovni stik vplivajo na leksiko in strukturo jezikov. Skupna Evropa prihodnosti se oblikuje kot večnarodni organizem. Glede na to se pojavlja vprašanje, kako bo potekalo sožitje različnih jezikov ter kultur in kakšna bo v praksi jezikovna politika. Med pravnim statusom nacionalnih jezikov in njihovim dejanskim položajem v praksi EZ obstajajo velike razlike. Ni še znano, kakšno stališče bodo do položaja svojih jezikov v EZ zavzele nove članice. Poleg uradnih in glavnih delovnih jezikov (angleščina, francoščina in nemščina) se za svoje pravice potegujejo tudi jeziki, ki nimajo statusa nacionalnih jezikov, npr. valižanščina, galicijščina in katalonščina. Večjezičnost EZ je hkrati prednost in ovira (npr. stroški, ki obremenjujejo proračun EZ). Čeprav je v naši civilizaciji jezik človekova najvišja vrednota (ne opravlja le vloge posredovanja informacij, temveč je tudi temelj simbolične kulture nekega naroda), se je treba zavedati, da na svetu vsaka dva tedna izumre en jezik; žal še ne poznamo pravih rešitev, kako ustaviti tako jezikovno umiranje - zdi se, kot da se bo še stopnjevalo. 